\title{
Cis-Hetero-Misogyny Online
}

\section{Louise Richardson-Self ${ }^{1}$}

Published online: 20 July 2019

(C) The Author(s) 2021, corrected publication 2021

\begin{abstract}
This article identifies five genres of anti-queer hate speech found in The Australian's Facebook comments sections, exposing and analyzing the ways in which such comments are used to derogate cisgender and (often) heterosexual women. One may be tempted to think of cis-het women as third-party victims of queerphobia; however, this article argues that these genres of anti-queer speech are, in fact, misogynistic. Specifically, it argues that these are instances of cis-hetero-misogynistic hate speech. Cis-hetero-misogyny functions as the "law enforcement branch" of a cis-hetero-patriarchal gender order. Given the existence of such an order, it is clear that cis-het women's liberation is inextricable from queer liberation (and vice versa). This article argues that to facilitate allyship and challenge this gender order - the order that elicits such hate speech acts - we need an epistemological revolution in the way we recognize and recognize human difference.
\end{abstract}

Keywords Online Misogyny $\cdot$ Hate Speech $\cdot$ Heterosexism $\cdot$ Cisgenderism $\cdot$ Feminism

This article identifies and assesses five genres of anti-queer hate speech found in The Australian's Facebook comments sections. (The Australian is a right-leaning daily national newspaper owned by News Corp Australia.) Sadly, verbal hostility towards the queer community is nothing new in Australia, which can be explained in light of its sociohistorical context. Australia only recently legalized same-sex marriage (2017), and prior to this change a non-compulsory postal vote was held to ascertain levels of public support. This included a campaign period where one group, the Coalition for Marriage, funded scare-mongering television advertisements which said "School told my son he could wear a dress next year if he felt like it"; "School programs have no place teaching my son radical gender ideas; that he might not be who he was born as"; and "How am I supposed to protect my kids in the future from this stuff?" (Richardson-Self 2018a, 34). This campaign period was also preceded by

\section{Louise Richardson-Self}

Louise.RichardsonSelf@utas.edu.au

1 University of Tasmania, Room 365, Humanities Building, Sandy Bay Campus, Hobart, Tasmania 7005 , Australia 
roughly 18 months of coverage across News Corp's media (including The Australian) of the Australian Christian Lobby's prejudicial attitude towards transgender status and its conservative opposition to the Safe Schools program - a national network of organizations working with schools to create safer and inclusive environments for queer students, staff, and families (Hunt 2018, 134). Recently, Tasmania also controversially legislated to remove gender records from new birth certificates unless parents opt-in. The Federal Government (allegedly) plans to override this law, with Liberal Prime Minister Scott Morrison lambasting the move as "ridiculous" on Twitter.

This article exposes and analyses the ways in which anti-queer comments are used to derogate cisgender $^{1}$ and (often) heterosexual women (hereafter 'cis(-het)' and 'cis-het'). One may be tempted to think of cis-het women as victims by association, or 'third-party victims' of queerphobia. However, I will argue that this anti-queer speech is, in fact, misogynistic hate speech-specifically, it is cis-hetero-misogynistic hate speech. ${ }^{2}$ Before I proceed, however, a few definitions are in order. The term 'cis-hetero-misogyny' is a portmanteau word meaning 'cisgenderist, heterosexist misogyny'. To call something heterosexist is to refer to the way individuals are presumed to be, and are always treated as though they are heterosexual (unless there are clear 'markers' that would indicate otherwise). Adrienne Rich calls this compulsory heterosexuality - an orientation towards the social world that affects every area of our lives (1980, 659). Likewise, to call something cisgenderist is to refer to the way individuals are presumed to be, and are always treated as though they are cisgender (unless there are clear 'markers' that would indicate otherwise). In structural parallel we may call this compulsory cisgenderism. Both also involve the tacit (false) assumption that when an individual is queer their queerness is always visually clear.

Importantly, I do not follow the standard definition of misogyny as the psychological state of hatred towards (all) women. Just as Brown has "explode[d] the myth that emotions, feelings, or attitudes of hate or hatred are part of the essential nature of hate speech" (2017a, 419), so has Manne with misogyny. We should instead understand misogyny as characterized by two traits: its coercive function as the 'law enforcement branch' of patriarchy, and its affective register of hostility (Manne 2018, 33). Misogynistic acts share a "social-cumstructural explanation: roughly, they must be part of a system that polices, punishes, dominates, and condemns those women who are perceived as an enemy or threat to the patriarchy" (Manne 2018, 34). Further, misogyny can be explicit or veiled; it can disguise itself in "the rewarding and valorizing of women who conform to gendered norms and expectations," where we often find it hiding within praise directed towards Good Women who do not challenged the status quo (Manne 2018, 72, original emphasis). Consequently, misogyny is not typically directed at all women. It is often intradivisional, aimed at policing Bad Women (RichardsonSelf 2018b, 264-267). ${ }^{3}$

To extend on Manne's analysis, cis-hetero-misogyny is primarily a property of social systems or environments as a whole, in which sex-, gender-, and orientation-diverse persons, as well as some cis-het women, will tend to face hostility of various kinds because they are sex-, gender-, and orientation-diverse persons in an androcentric, sexually dimorphic,

\footnotetext{
${ }^{1}$ The term 'cisgender' refers to those whose gender identity is 'on the same side' as the designation of sex/gender at birth (Aultman, in Currah et. al. 2014, 61).

${ }^{2}$ This article adopts Richardson-Self's (2018b) stance that all misogynistic speech is hate speech. Thus, derivatively, cis-hetero-misogynistic speech also constitutes hate speech. It also takes for granted that hate speech should be regulated.

${ }^{3}$ Note that I capitalize 'Man' and 'Woman' to signal the concept as figured under cis-hetero-patriarchy.
} 
cisgenderist, heterosexist world (i.e. a cis-hetero-patriarchy), who are held to be failing to live up to cis-hetero-patriarchal standards, or because they actively challenge these standards in some way, including by being visually Other. Because of this, cis-hetero-misogynistic hostilities will strike quite generally to visibly non-normative persons, since-unlike cis-het women, who may attempt to model themselves as "men's attentive, loving subordinates" (Manne 2018, 49) - sex-, gender-, and orientation-diverse persons present a challenge to this gender ideology in their very visible presence. Cis-het women, by contrast, will face such hostilities selectively, depending on whether they are perceived as 'Good Women' or 'Bad Women' (2018, 33-34, 47).

However, if heterosexuality and cisgenderism are truly compulsory, then all misogyny is always cis-hetero-misogyny. I accept this, but I want to use these term 'cis-hetero-misogyny' to capture a specific kind of misogynistic speech. What is the difference between calling a cis -het woman a "slag," "hag," or "bitch," versus a "dyke," "bloke," or "It"? My suggestion is that the former-call it classic misogyny - tacitly assumes that a woman is cis-het and criticizes her for performing her normative role poorly: she is not chaste enough for Man, not pretty enough for Man, or not nice enough for Man. But the latter type of speech - cishetero-misogyny - accuses a cis(-het) woman of failing to be cisgender/heterosexual in the first place. While the woman targeted with classic misogyny is surely a Bad Woman, the woman targeted with cis-hetero-misogyny does not classify (or hardly classifies) as a Woman at all; she is undeserving of being recognized as a Woman.

While the women discussed here have all been targeted by classic misogyny as well as cishetero-misogyny, I focus on the latter in the remainder of this article. This is because several genres of this speech are novel, and seem to be a product of and a reaction to increasing queer recognition in Australia, given the gender-centered anxieties described above. Further, because this speech, when taken contextually, looks to be 'simply' anti-queer rhetoric, we can lose sight of the fact that what drives this speech, at base, is the fact that cisgender women are challenging the status quo, i.e. challenging men's social power. This is not just queerphobia. It is also misogyny, and its effect is to perpetuate cis-hetero-patriarchy. We must therefore recognize that cis-het women's liberation is inextricable from queer liberation (and vice versa), and this should serve as a directive for allyship in the present. In closing, I will argue that in order to facilitate such allyship and challenge the patriarchal gender order that elicits such hate speech acts, we need an epistemological revolution in the way we recognize and re-cognize human difference.

\section{Method}

This data set is comprised of publicly available Facebook comments left in response to articles shared by The Australian. This publication is Australia's only national daily newspaper, with twice as many readers online versus print (Roy Morgan 2017), and over 830,000 Likes on Facebook as of February 28, 2018. Facebook is the largest social networking site, with 2.07 billion monthly users (Facebook Newsroom 2017). The data were collected manually one day after the initial Facebook post, and were drawn systematically from any article shared by The Australian which mentioned genderrelated issues (e.g. domestic violence; workplace quotas; feminism), which focused on prominent female figures (e.g. sporting stars; politicians; CEOs; authors), or which featured women in the thumbnail attached to the article in the original post. In comments 
sections with fewer than 100 comments, both primary comments and secondary replies were collected. In comments sections with greater than 100 comments, only primary comments were collected.

Across a six-month period of manual data collection of misogynistic and sexist online comments, 52 high-profile cisgender women were attacked with cis-hetero-misogynistic comments (as seen in Table 1), and I focus on the 11 women with the most comments. Overall, there were 463 cis-hetero-misogynistic attacks made within 419 comments by 287 different commentators.

Altogether, this is $2.5 \%$ of my larger data set (16,643 comments). While this is a small percentage, I take seriously Waldron's idea that the literal look of our social spaces matters greatly to the assurance oppressed groups have that they will be treated with the dignity and respect they are owed qua group - the assurance that there is "a general commitment to the fundamentals of justice and dignity" in that society $(2012,69)$.

As such, I think it is worthwhile to qualitatively analyze this speech so as to better understand why this pattern has emerged, what work the speech is doing, and how we might develop strategies to prevent such hate speech acts in the future. Before moving onto this task, however, it is also interesting to note that, on the basis of the gender of the Facebook name, there appear to have been 223 men commentators, 62 women commentators, and 2 indeterminate commentators. Women, therefore, were responsible for $22.6 \%$ of the total comments, while men were responsible for $76.7 \%$ of these comments. Each commentator has been given a pseudonym and all women commentators' names have been italicized. When someone is a repeat commentator targeting the same individual woman, their names have been emboldened. When someone is a repeat commentator targeting several women, their names have been emboldened and underlined. All comments are reproduced verbatim, and replies are indented after the original comment.

\section{Results}

The cis-hetero-misogynistic speech I have collected can be divided into five genres: lesbian-baiting, assertions of gender non-conformity, degradation via misgendering, degradation via missexing, and androgynising. While the first two genres will be familiar to many women, the latter three genres are quite new (though they can only be made sense of in relation to the first two genres and with reference to historicocontextual factors). Let us consider each genre in turn.

Lesbian-Baiting: Accusing a woman of being a lesbian, or simply pointing out that a woman is a lesbian, is a well-established tactic used to undermine women, to degrade them, and/or coerce them into compliance with patriarchal norms of Womanhood. Cheshire Calhoun calls this "lesbian baiting," where women who fail to comply with sexuality norms are threatened with the social stigma of queerness which serves to uphold the institution of compulsory heterosexuality $(2000,141-142)$. Though there is certainly less stigma directed towards samegender sexual attraction today as compared to previous decades, some have argued that such tolerance has been dependent on queers mimicking heteronormative lifestyles, meaning that those queers who cannot — or will not—-structure their intimate lives accordingly are still prime targets of prejudice (Richardson-Self 2015, 72). In short, the political institution of compulsory heterosexuality has not been fully dismantled; subsequently, accusing a woman of such 
Table 1 Targets of Cis-hetero-misogynistic Comments

\begin{tabular}{|c|c|c|}
\hline Target & Public Role & Attacks \\
\hline Kerryn Phelps & Former Independent Member of Federal Parliament & $19.87 \%(92)$ \\
\hline Michelle Obama & Former First Lady of the United States & $13.82 \%(64)$ \\
\hline Sally McManus & Secretary to the Australian Council of Trade Unions & $12.74 \%(59)$ \\
\hline Serena Williams & Tennis World Champion & $7.78 \%(36)$ \\
\hline Penny Wong & Federal Labor Senator & $4.75 \%(22)$ \\
\hline Julia Banks & Former Liberal/Independent Member of Federal Parliament & $4.54 \%(21)$ \\
\hline Bec Cody & $\begin{array}{l}\text { Member of the Australian Capital Territory Legislative } \\
\text { Assembly (Labor) }\end{array}$ & $3.67 \%(17)$ \\
\hline Kelly O’Dwyer & Former Liberal Member of Federal Parliament & $3.02 \%(14)$ \\
\hline Renae Lawrence & Member of the Bali 9 (convicted drug trafficker) & $2.59 \%(12)$ \\
\hline Christine Forster & Liberal Councillor in the City of Sydney & $2.16 \%(10)$ \\
\hline Regina Wilson $^{\mathrm{a}}$ & High School Teacher & $2.16 \%(10)$ \\
\hline Peta Credlin & $\begin{array}{l}\text { Political Commentator and Chief of Staff to Former Prime } \\
\text { Minister Tony Abbott }\end{array}$ & $1.73 \%(8)$ \\
\hline Hannah Gadsby & Australian Comedian & $1.73 \%(8)$ \\
\hline Julia Gillard & Former Prime Minister of Australia & $1.51 \%(7)$ \\
\hline Julie Bishop & $\begin{array}{l}\text { Former Liberal Member of Federal Parliament/Deputy } \\
\text { Leader of the Liberal Party }\end{array}$ & $1.30 \%(6)$ \\
\hline Anna Wintour & Vogue Editor in Chief & $1.30 \%(6)$ \\
\hline Rahaf Mohammed Alqunun & Saudi Arabian Refugee (granted asylum in Canada) & $1.08 \%(5)$ \\
\hline Emma Husar & Former Labor Member of Federal Parliament & $1.08 \%(5)$ \\
\hline Annastacia Palaszczuk & Premier of Queensland (Labor) & $1.08 \%(5)$ \\
\hline Rebekha Sharkie & Centre Alliance Member of Federal Parliament & $1.08 \%(5)$ \\
\hline Sarah Hanson Young & Federal Greens Senator & $0.86 \%(4)$ \\
\hline Tanya Plibersek & Labor Member of Federal Parliament & $0.65 \%(3)$ \\
\hline Jacinda Ardern & Prime Minister of New Zealand & $0.43 \%(2)$ \\
\hline Gladys Berejiklian & Premier of New South Wales (Liberal) & $0.43 \%(2)$ \\
\hline Raelene Castle & Chief Executive Officer of Rugby Australia & $0.43 \%(2)$ \\
\hline Amal Clooney & Human Rights Lawyer (wife of actor George Clooney) & $0.43 \%(2)$ \\
\hline Germaine Greer & Second-Wave Feminist Writer & $0.43 \%(2)$ \\
\hline Kate Jones & Member of the Queensland Legislative Assembly (Labor) & $0.43 \%(2)$ \\
\hline Cathy McGowan & Former Independent Member of Federal Parliament & $0.43 \%(2)$ \\
\hline Angela Merkel & Chancellor of Germany & $0.43 \%(2)$ \\
\hline Montaigne & Musician & $0.43 \%(2)$ \\
\hline Sandra Nelson & Member of the Northern Territory Legislative Assembly (Labor) & $0.43 \%(2)$ \\
\hline Cynthia Nixon & Actress, Activist, and Political Hopeful & $0.43 \%(2)$ \\
\hline Marise Payne & Liberal Member of Federal Parliament & $0.43 \%(2)$ \\
\hline Lucy Turnbull & Wife of Former Prime Minister Malcolm Turnbull & $0.43 \%(2)$ \\
\hline Roz Ward & Safe Schools Coalition Australia Founder & $0.43 \%(2)$ \\
\hline Katie Allen & Liberal Member of Federal Parliament & $0.22 \%(1)$ \\
\hline Anne Aly & Labor Member of Federal Parliament & $0.22 \%(1)$ \\
\hline Ali Brigginshaw & Australian International Rugby League Player & $0.22 \%(1)$ \\
\hline Linda Burney & Labor Member of Federal Parliament & $0.22 \%(1)$ \\
\hline Kate Daly & Australian International Rugby League Player & $0.22 \%(1)$ \\
\hline Joy Damousi & President of the Australian Academy of the Humanities & $0.22 \%(1)$ \\
\hline Kristin Ferguson & Acting Chair of the Australian Broadcasting Corporation Board & $0.22 \%(1)$ \\
\hline Michelle Guthrie & $\begin{array}{l}\text { Former Managing Director of the Australian Broadcasting } \\
\text { Corporation }\end{array}$ & $0.22 \%(1)$ \\
\hline Sue Hickey & Speaker of the Tasmanian House of Assembly & $0.22 \%(1)$ \\
\hline Annamarie Jagose & LGBT Academic and Author & $0.22 \%(1)$ \\
\hline Meghan Markle & Actress, wife of Prince Harry Duke of Sussex & $0.22 \%(1)$ \\
\hline Theresa May & Prime Minister of the United Kingdom & $0.22 \%(1)$ \\
\hline Niki Sava & Australian Journalist & $0.22 \%(1)$ \\
\hline Carmel Tebutt & Former Member of the New South Wales Legislative Assembly & $0.22 \%(1)$ \\
\hline Alice Thompson & Advisor to Former Prime Minister Malcolm Turnbull & $0.22 \%(1)$ \\
\hline Jennifer Westacott & Chief Executive of the Business Council of Australia & $0.22 \%(1)$ \\
\hline Total & & $100.04 \%$ \\
\hline
\end{tabular}

The total number of cis-hetero-misogynistic attacks is reported in brackets.

a Wilson is an anomaly insofar as she was the only woman to be targeted who was not already a high-profile public figure before being reported on by The Australian. 
Table 2 Lesbian-Baiting

\begin{tabular}{|c|c|}
\hline At Phelps. & $\begin{array}{l}\text { "Phelps is a carpet munching muesli eating sandal wearing leftist shitcunt" —Floyd. } \\
\text { "Just stick to lickin vag" - Will. }\end{array}$ \\
\hline \multirow[t]{2}{*}{ At McManus. } & "Shouldn't she be eating carpet somewhere?" —Warwick. \\
\hline & $\begin{array}{l}\text { "Not sure what a lesbian gender activist has in common with coal miners and } \\
\text { construction workers... perhaps the union movement is out of touch?" - Alex. }\end{array}$ \\
\hline \multirow[t]{2}{*}{ At Wong. } & "Madam Wong must've been wearing her 'Strap On' today....” —-Teddy. \\
\hline & $\begin{array}{l}\text { Also targeting Phelps and Forster: "Oh dear...2 lesbos with their claws out! } \\
\text { Where is Penny Wong to make it really interesting? } \\
\text { [5x laugh-cry emoji]"-Parker. }\end{array}$ \\
\hline \multirow{2}{*}{ At Banks. } & Also indicating Phelps: "DILDO QUEENS?????????"-Reginald. \\
\hline & $\begin{array}{l}\text { "Its like a rug-muncher version of Celebrity Death Match - Phelps \& Ms. } \\
\text { Banks vs Gillard \& Penny Wong to see who can smash the most clam } \\
\text { in 3:00mins" - Theo. }\end{array}$ \\
\hline \multirow[t]{2}{*}{ At Cody. } & "Lbgtq avenue" - $\overline{\text { Francisco. }}$ \\
\hline & "Typical Rug Muncher to sensitive" —Franklin. \\
\hline \multirow{2}{*}{$\begin{array}{l}\text { At Forster (also } \\
\text { indicating Phelps). }\end{array}$} & "A homosexual derby" —Zane. \\
\hline & $\begin{array}{l}\text { "women who broke their vows of marriage to be with women? This is } \\
\text { representative government how?" - Gill. }\end{array}$ \\
\hline \multirow[t]{2}{*}{ At Wilson. } & "Why is it always the lesbos who act like this?" - Ned. \\
\hline & "Lesbos, that's an island off Greece [Greek flag emoji] cuzzie" —Zareen. \\
\hline
\end{tabular}

preferences (or pointing to a cisgender woman's actual same-gender sexual preferences) can still undermine her, misdirect attention from the social action she is undertaking, or derail a discussion (see Table 2). Commentators highlight these women's (alleged) marginal identity, their failure to conform to heteroromantic ideals, and also make animalistic implicatures. In so doing they arguably undercut these women's status, respectability, and authority, but they do so in ways that do not track the actual status of the chosen women's sexual orientation. Note that Phelps, Wong, Forster, and Lawrence are all openly lesbians, yet Lawrence was not targeted with lesbian-baiting, while other women who are known to be heterosexual were.

Assertions of Gender Non-Conformity (with Lesbian-Baiting) While the examples of lesbianbaiting in Table 2 involve simply asserting that a woman is same-gender attracted or engages in same-sex sexual activity, women are also lesbian-baited via commentary on their 'masculine' appearance. This is encapsulated in the epithet "dyke". The conflation of masculinism and samesex sexual activity dates back to at least Ancient Rome, where such women were seen to be "selfdeluded and inept...trying to be manly (or to be men) and making a very bad job of it" (Baltzly 2003, 23). But we should also note, as Scharff explains, that within the logic of a patriarchal gender order, "the spectre of the unfeminine man-hater [is] the constitutive outside of normative femininity" $(2012,85)$. The derivative idea is that women who are read as 'masculine' "must desire like men and, following a heterosexual logic, therefore be attracted to women" (Scharff 2012, 76). Thus, women who are simply 'unfeminine,' whether by virtue of their behavior or appearance, may be targeted with hostility, even if they are not also read as 'lesbians', because they are not performing the role of Woman properly (Table 3). Such comments do not only misdirect, derail, or obfuscate, they explicitly show contempt for gender- and (presumed) sexual-nonconformity, but once again the comments do not strictly track women who are in fact lesbians or who do in fact 'read' visually as masculine.

Degradation Via Misgendering Beyond assertions of gender non-conformity are comments asserting that the woman in focus is not actually a masculine woman, but is 'really' a man. This 
Table 3 Asserting Gender Non-Conformity

\begin{tabular}{|c|c|}
\hline \multirow[t]{2}{*}{ At Phelps. } & "She looks like a bull dyke.."-Dev. \\
\hline & $\begin{array}{l}\text { "No problem with more women in parliament, what we do not need is } \\
\text { more women who look like men,dress like men and think like men"-David. }\end{array}$ \\
\hline \multirow[t]{2}{*}{ At Obama. } & “Obama looks like a man.”-Flora. \\
\hline & $\begin{array}{l}\text { "Maybe the SJW [social justice warrior] morons are jealous because she } \\
{[\text { Melania Trump] doesn't resembele a man like Michelle O? [...]"-Palmer. }}\end{array}$ \\
\hline \multirow[t]{2}{*}{ At McManus. } & $\begin{array}{l}\text { "Is it just me, or does she look like Quagmire from The Family Guy? Giggity } \\
\text { Giggity"-Finnegan. }\end{array}$ \\
\hline & "You WOULD expect this sort of comment from this dyke looking idiot!"--Luke. \\
\hline \multirow[t]{2}{*}{ At Williams. } & $\begin{array}{l}\text { "Nothing wrong with the cartoon [of Williams, published in the Herald Sun], } \\
\text { she looks like a bloke!!"-Hale. }\end{array}$ \\
\hline & "definitely transforming as she ages into more male than female appearance"-Olive. \\
\hline \multirow[t]{2}{*}{ At Wong. } & $\begin{array}{l}\text { "Wenny Pong.../Such a Muppet this woman is (well at least I think she is a woman) } \\
{[\ldots] " \text {-Parker. }}\end{array}$ \\
\hline & $\begin{array}{l}\text { Responding to a picture of former Federal Labor leader Bill Shorten, Wong, and } \\
\text { Plibersek: "Do they all go to the same barber?"-Harold. }\end{array}$ \\
\hline At Banks. & $\begin{array}{l}\text { "Accurate thumbnail of JB [Banks] and others like her [...]"-Niles\&Marg. } \\
\text { Thumbnail is a caricature where Banks looks especially older and masculine in } \\
\text { the face, in spite of obvious feminine markers like lipstick, earrings, and long hair. }\end{array}$ \\
\hline \multirow[t]{2}{*}{ At Cody. } & $\begin{array}{l}\text { "The lesbian haircut should be a warning that she's trouble. Who keeps electing } \\
\text { these idiots to represent people?"-Paton. }\end{array}$ \\
\hline & $\begin{array}{l}\text { "this is an ANTIFA troll, the next demand will be to tear down statues of famous } \\
\text { people. Doesn't that plaid shirt look so butch? [...]"-Tate. }\end{array}$ \\
\hline At Forster (also & "I want to vote for a feminine gay women. Where are they?"-Gavin. \\
\hline
\end{tabular}

is not an altogether surprising evolution of anti-woman rhetoric since, as Scharff explains, "there is no space for women to be unfeminine without also being manly" $(2012,73)$. Here, we should note an important point made by Jay: there is a "persistent relation between conservativism and rigid gender dichotomy" (1981, 50). And since there is no space for women to be unfeminine without also being manly, it is just one short step from accusations of gender non-conformity to direct misgendering of cis(-het) women. Examples of this genre are found in Table 4. Understood as an extension, we can see why perceived or presumed gender non-conformity by cis(-het) women is being socially policed, and even though the speech acts themselves seem to be benign jokes, they function to maintain an unjust patriarchal status quo and undermine the assurance women and queers have in their likelihood of being treated with dignity.

Degradation Via Missexing Alongside assertions that the women in question are 'really men', commentators also relatedly asserted that these women are 'not really female'. Such comments are often difficult to tease apart from comments which degrade via misgendering, since both heterosexism and cisgenderism intersect, collectively taken for granted as the norm. Indeed, the same logic which leads to the misgendering discussed above is also that which leads to missexing (Table 5). ${ }^{4}$

These hostilities appear to be both grounded in a habitual attitude which holds that "a medical professional's cursory genital observation instantiates gender/sex at birth" (Van

\footnotetext{
${ }^{4}$ Race likely plays a role in the missexing of Wong, Williams, and Obama. However, race is not a determining factor in such treatment, for the Liberal Senator for South Australia Lucy Gichuhi and Federal Greens Senator Mehreen Faruqi both faced racism and classic misogyny in this period, but not cis-hetero-misogynistic comments.
} 
Table 4 Misgendering

\begin{tabular}{|c|c|}
\hline At Phelps. & $\begin{array}{l}\text { "I might vote for kerryn .he seems like a nice bloke"-Fred. } \\
\text { "Very ugly man with selfish plan, traitor"-Felipe. }\end{array}$ \\
\hline At Obama. & "we don't care what that ..bloke Michelle thinks..." - Olivia. \\
\hline At McManus. & $\begin{array}{l}\text { "He is one ugly bloke"- Gerald. } \\
\text { "This man is a moron"- Nolan. }\end{array}$ \\
\hline At Williams. & $\begin{array}{l}\text { "This Serena bloke really needs to learn some manners"- Dale. } \\
\text { "Serena = Man"-Willem. }\end{array}$ \\
\hline At Wong. & $\begin{array}{l}\text { "Who is that bloke?"-Hal. } \\
\text { "Who is this Penny Wong? I've never heard of him before."-Gill. }\end{array}$ \\
\hline $\begin{array}{l}\text { At Banks. } \\
\text { At Cody. }\end{array}$ & 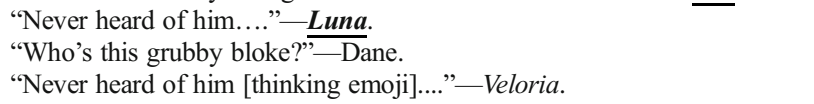 \\
\hline At O’Dwyer. & $\begin{array}{l}\text { "He's nuts!"-Norman. } \\
\text { "O'dwyer is a man isn't she?????"-Pedro. }\end{array}$ \\
\hline At Lawrence. & $\begin{array}{l}\text { "Welcome home fella...stay away from drugs."-Ringo. } \\
\text { "Lock that bloke up when he gets back"-Daryl. }\end{array}$ \\
\hline At Forster. & "He reminds me of Turnbull."-Paul. \\
\hline
\end{tabular}

Anders, in Currah et. al. 2014, 33), and is consistent with conservative views that have been increasing in the past three-to-four years within mainstream right-leaning media (discussed in the introduction). Given that trans and non-binary people pose a symbolic threat to both the notion of gender and the security of sex, trans-directed antagonism is unsurprising. Yet this speech is doing something more, for it is used to target cis(-het) women; it polices cis(-het) women with the threat of being positioned as radical, extreme, transgressive, and Bad, so as to turn them away from contesting the status quo and from developing radical alliances with the queer community.

Nonbinary/Intersex Aversion The final form which these comments take is withholding a gender ascription to the woman in question, implying intersex and/or gender non-binary status. This genre is also related to misgendering and missexing, but now we see the pretense of confusion, as though one cannot readily decipher the woman's sex or gender (Table 6). Note that cisgender dimorphism seems to configure itself through the abjection of sex and gender non-conformity; hence, what is androgynous is precisely what is "unsymbolisable, unspeakable, illegible" (Butler, in Scharff 2012, 82). If correct, one function of this speech is that it abjectifies cisgender women; it renders them disgusting. Remember, while the actual presentation of androgyny may elicit genuine abject responses (though this is objectionable), the women targeted do not present as such; no one is genuinely confused as to the gender status of these women. What is particularly interesting about this move is that it also dehumanizes these women by making them into 'its' or 'things'.

\section{Discussion}

How should we make sense of this pattern of hate speech and the emergence of new genres of cis-hetero-misogyny? Why are men (overwhelmingly) and women (to a lesser degree) doing this? What is this speech supposed to do, and what can we learn from analyzing it? I consider each of these questions in turn. (Note that what follows is what I take to be the most plausible explanation for the identified behavior and not an account of the commentators' intentions.) 
Table 5 Missexing

\begin{tabular}{|c|c|}
\hline At Phelps. & $\begin{array}{l}\text { "Is she transitioning? / Or is it just me? [5x kiss emoji] - Patrick. } \\
\text { "Oh gawd, here we go, the crap never stops from this "woman"-Faun. }\end{array}$ \\
\hline \multirow[t]{2}{*}{ At Obama. } & $\begin{array}{l}\text { "[...] Please go away or follow Bruce Jenner into the hall of fame of cocks in } \\
\text { frocks."-Peter. }\end{array}$ \\
\hline & $\begin{array}{l}\text { "Michael wrote a book? Does it have a chapter on tucking away the twig and } \\
\text { berries?"- Thomas. }\end{array}$ \\
\hline At McManus. & $\begin{array}{l}\text { "Did I see someone say that is a female. No way, that is an ugly bloke"-Victor. } \\
\text { "No woman is that ugly. It has to be staged."-Victor. }\end{array}$ \\
\hline At Williams. & $\begin{array}{l}\text { "He [Serena's umpire] was obviously transphobic"-Thomas. } \\
\text { "watch serena lose to a man that still has a penis"- } \mathbf{\text { Winston. }}\end{array}$ \\
\hline $\begin{array}{l}\text { At Wong (also indicating } \\
\text { Hanson-Young). }\end{array}$ & $\begin{array}{l}\text { "Both of these 'women' are man haters."-Flo. } \\
\text { "Women????"-Amanda. }\end{array}$ \\
\hline At Banks. & $\begin{array}{l}\text { Also indicating Bishop: "First glance i thought was } 2 \text { Drag Queens."-Tex. } \\
\text { Also indicating Phelps and Sharkie: "[...] at least show a picture of } 3 \\
\text { women..."-Hector. }\end{array}$ \\
\hline At Cody. & "Is it a women"-Warren. \\
\hline \multirow[t]{2}{*}{ At O’Dwyer. } & $\begin{array}{l}\text { "Clearly they [the Liberal Party] aren't transphobic or useless phobic [because } \\
\text { O'Dwyer is a member]." Sarah. }\end{array}$ \\
\hline & "One drag queen leaves parliament then a man takes over"-Pedro. \\
\hline \multirow[t]{4}{*}{ At Forster. } & "What happened to the sisterhood ladies?"-Walker. \\
\hline & "there are 'ladies' in the sisterhood? [shocked emoji]"-Lisa. \\
\hline & "He would screw us like Turnbull would he?[laugh-cry emoji]"-Levi. \\
\hline & "Yes \\
\hline
\end{tabular}

From the foregoing we can clearly see that there has been an evolution in cis-heteromisogynistic speech. The first two genres are familiar to many women as examples of (cis-)hetero-misogyny, since lesbianism has been often viewed as "a form of nay-saying to patriarchy, an act of resistance" which needs to be quashed (Rich 1980, 649). And given the long historical association of masculinity (whether via behavior or through appearance) with same-sex sexual desire, we have often seen hostile disparagement of 'masculine women' too. But here we witness three new-yet not isolated - genres. No longer is a woman simply disparaged for 'trying to be a man' and making a very bad job of it. Women who are known to be cisgender are now being explicitly misgendered, missexed, and androgynised. She now is a

Table 6 Androgynising

\begin{tabular}{|c|c|}
\hline At Phelps. & $\begin{array}{l}\text { "Who'd vote for a gender bender not I"-Quaid. } \\
\text { "[...] she is a typical nasty vicious big mouthed it."-Louise. }\end{array}$ \\
\hline At Obama. & $\begin{array}{l}\text { "What a hateful "thing" she is! For self - not America!"-Violet. } \\
\text { "[... \#heorshe?"-_Parker. }\end{array}$ \\
\hline At McManus. & $\begin{array}{l}\text { "The real question is "what" is Sally McManus? It's hard to tell by looking."-Deakin. } \\
\text { "What that is? Is that a gender neutral person?"-Nate. }\end{array}$ \\
\hline At Williams. & $\begin{array}{l}\text { "It' is nothing more than a foul mouthed sook"- -Maury. } \\
\text { "Serena She/he gonna pee there??????? How??????-Leonardo. }\end{array}$ \\
\hline At Wong. & $\begin{array}{l}\text { "And we pay for penny not sure of gender wong"-Winter. } \\
\text { "He or she??"-Paco. }\end{array}$ \\
\hline At Banks. & "Julia Banks and Kerryn Phelps dont vote for these"-Lukah. \\
\hline At Cody. & $\begin{array}{l}\text { "Just look at it!"-Raine. } \\
\text { "Tell her she's/he's dreaming."_-Freya. }\end{array}$ \\
\hline At O’Dwyer. & "it's a farking idiot anyhow"-Damien. \\
\hline At Lawrence. & $\begin{array}{l}\text { "she should go straight to Tasmania where she can work out her gender"-Ryan. } \\
\text { "Free hot shot for him/her/it?"-W Waleed. }\end{array}$ \\
\hline At Wilson. & $\begin{array}{l}\text { "Just take one look at her. Seriously, would you want this thing teaching your kids?"- } \text { Tahlia } \\
\text { "Why does IT still have ITS job?"-Zack. }\end{array}$ \\
\hline
\end{tabular}


man/male, and this is understood to be a bad thing, or, worse still, we cannot be sure what she really is. Recent events in the Australian context clearly highlight why such commentary has evolved into these rather than other forms, but it is important to recognize that this is not just queerphobia. Cis(-het) women are not simply third-party victims; this is misogyny.

According to a patriarchal gender order, these women are all, in their own ways, "missstepping, or over-stepping, or deviating, or wronging" Man, and their social policing is the consequence (Manne 2018, xvii). Consider that Phelps ran for and briefly secured the Federal seat of Wentworth, a historically conservative seat held exclusively by men. Obama is a successful, educated, Black woman, as well as the wife of the first African-American President, who published a memoir about her personal journey. McManus, as the Secretary of the ACTU, is the face of the movement for the working class, though the stereotype of the working-class hero has always been that of a man. Williams did not receive any form of negative media commentary during the six-month collection period until she accused an umpire of sexism during the US Open. Wong is openly a lesbian, a successful progressive politician, and was a strong advocate for same-sex marriage. Similarly, though Forster is a conservative, she publicly opposed her brother, former Prime Minister Tony Abbott's stance on same-sex marriage. O’Dwyer and Banks are also conservatives, yet Banks left the Liberal Party due to alleged male bullying, while O'Dwyer publicly warned that the Liberal Party was developing a reputation for homophobia and sexism. Wilson made headlines for allegedly attempting to encourage her students not to become Liberal Party voters in the future. Cody wants to revise certain place names so that they meet community standards by no longer glorifying the legacies of historic (often male) figures who have committed past atrocities. Finally, Lawrence is a masculine-presenting 'out' lesbian as well as a law-breaker. Yet which women will be targeted, and who will become a frequent target seems almost impossible to predict.

Bizarrely, there seems to be no clear rhyme or reason to this pattern. All these women have challenged the status quo in some way, and this appears to be a necessary condition of becoming a target; yet it is not a sufficient condition, for other women challenged the status quo in the same period - e.g. Lucy Gichuhi and Mehreen Faruqi - and received no comments of this kind. (They did receive other negative comments though, such as racist or classically misogynistic comments.) All known lesbians who appeared in the media during this period were targeted, but so were some straight women - so, we may perhaps say that lesbianism is a sufficient though not necessary condition of becoming a target. Yet we should also note that some lesbians received far more attention than others, and it is not at all clear why. Further, some lesbians were not disparaged for their sexual orientation, but were targeted with the other genres of cis-hetero-misogyny. While many women of color were targeted, others were not, so race is not predictive. While some left-wing women were targeted, so were centrist and rightwing women, so political ideology is not predictive. Given this, I believe the lack of rhyme or reason in determining which women will be targeted sends a message to all women: they are liable to be treated thus if they challenge the status quo in any way whatsoever and for the benefit of any oppressed group whatsoever, which is to say that challenging the status quoand therefore creating a more just society—remains risky business for women in the Australian context today.

It seems clear that men comment most frequently because they are the most invested in maintaining a patriarchal gender order. As we have already seen, two taken for granted stereotypes in a patriarchal gender order are that Men and Women are naturally heterosexual and cisgender. But there is another view so taken for granted, so 'given', which remains at the 
core of patriarchal ideology: while Man is the paradigm exemplar of individual agency (after all, the individual liberal Subject is modelled after him), Woman is his helpmeet. Man is entitled to the supportive services of Woman in dedicated pursuit of his aims, according to the logic of patriarchy, and Woman is obliged to provide Man with "affection, adoration, indulgence, ... simple respect, love, acceptance, nurturing, safety, security, and safe haven," and other feminine-coded interpersonal goods and services (Manne 2018, 110). Given all of this, since these women challenge the status quo in various ways, and since compulsory heterosexuality and cisgenderism, as well as sexism, are sources of male power (Rich 1980, 638), men's repetition of this type of speech act should be understood as an (attempted) exercise of this power in order to protect the current gender order. But this is not about policing the particular individuals identified here; rather, these comments are ultimately intended to show ordinary (low profile) cis(-het) women what constitutes a crossing of the line and what behavior one can expect to be reprimanded for. In so doing, the commentary also simultaneously licenses the policing of this line by others. But if these speech acts work to reinforce a patriarchal gender order, what can explain why women also engage in this activity? Well, a woman who engages in this punching-down behavior, it seems clear, seeks to position herself as worthy of (cis-het) men's respect through her speech acts. After all, a Good (cis-het) Woman does not want to be perceived as an unbecoming woman, a "traitor to the cause of gender" (Manne 2018, 51). Again, this is an interpretive explanation, rather than an account of the conscious intentions of these women commentators.

Though many readers will likely be unsurprised that challenging the status quo is a risk for any woman, the fact that hate speech acts in the form of cis-hetero-misogyny are repeatedly chosen as a policing tactic itself demands our critical attention. We can use the above-described account of cis-hetero-misogyny like three-dimensional glasses to see the depth in this novel pattern of online commentary targeting cisgender and (often) heterosexual women. Though this speech initially appears benign, as more of a joke than an oppressive action, with this lens we see why such an interpretation is limited and problematic. This speech is intended to police patriarchy, but it also works by disincentivizing allyship between cis-het women and queer women (including transwomen). Through disguising itself as simply anti-queer speech, obscuring its misogynistic motivations, cis-het women are offered the 'choice' of Good behavior; they can show their allegiance by accepting men's invitation into their hate world, accommodating a presupposed cis-hetero-patriarchal metaphysics (Langton 2012, 86-89).

So, what should feminists be focusing on presently to combat patriarchy? To start, note that patriarchal gender orders have a distinct epistemology. They start with the Principle of Identity $-A=A$. This principle is foundational to our logos - our unified conceptual order through which we make sense of the world - and is accompanied by the Principle of Contradiction - Not (A and Not-A) — and the Principle of the Excluded Middle where "anything, and everything, must be either $A$ or Not- $A$ " (Jay 1981, 42, my emphasis). In this logos we often latently and quite automatically interpret our world according to a logic where there can only be either total sameness $(A=A)$ or complete otherness $(A \neq N o t-A)$, with nothing in between. Importantly, $A$ is a positive presence, whereas $N o t-A$ is defined in terms of what it lacks (namely, $A$ ) rather than being defined in its own right (Gatens 1991, 93). Thus, our logos "operates by way of dichotomous thought, where one central term defines all others only in terms relative to itself" (Gatens 1991, 94). And since one has a positive presence while the other is both lacking and defined relationally, we find that one of the terms is always positioned as "primary" (Gatens 1991, 112). 
In short, our habituated logic, which is the only logic, is "founded on the exclusion and binary polarization of difference," disavowing what deviates from the norm, i.e. A (Grosz 1989, xix). Here, note that normalcy invokes two meanings. On the one hand, 'normal' signifies the regular, or conformity, yet on the other hand it also signifies one's being morally upright. In other words, 'normal' reflects both the mundane everyday standard as well as the moral ideal (Stephens, in Currah et al. 2014, 142). As patriarchy is androcentric, Man is the implicit standard- $A$-against which all Others are defined. Consider Beauvoir's telling observation "A man never begins by positing himself as an individual of a certain sex: that he is a man is obvious. ... it is understood that being a man is not a particularity... there is an absolute human type that is masculine" $(1949,5)$. Thus, we can see why Woman or The Queer - those who are not 'the norm' - become stigmatized in particular ways, for they are structured as 'abnormal' and abnormality carries this dual implication. Further, these Principles are tacitly and habitually applied, and "covertly promote social and political values by presenting a conceptual division as though it were a factual or natural division" (Gatens 1991, 92). So, we cannot but note that Man's positive definition as the paradigm normative human Subject $(A)$ necessitates the perception of Woman/Queer as deviant, lacking, and lesser than him.

Focusing on the intersection of this latent epistemology or structuring logic with the aforementioned three taken for granted social orientations - compulsory heterosexuality, compulsory cisgenderism, and the subordinate status of Woman to Man-we see clearly that this gender order involves:

a. the bifurcation of humanity into 'male/active' and 'female/passive' types;

b. the polarization of these dichotomies into mutually exclusive, or even opposing composites via the Principles of Order;

c. penalization for sex/gender atypicality or transitivity; and

d. devaluation of the feminine, including persons who are feminized - hence, cis-het women and queers become 'the Other' (cf. Valdes 1996, 170).

I believe, with this epistemological meta-awareness, we can combat the patriarchal logocentrism that entrenches these 'truths' and hence enables and encourages the speech acts I have identified. While there is nothing oppressive about logocentrism in and of itself, "it is necessarily distorting when it is applied to the empirical world;" it becomes mistaken for metaphysical, unchanging reality, and this is a problem (Jay 1981, 48).

Aside from educating for the epistemological meta-awareness just mentioned, the new slogan popular within some feminist circles - "support your sisters, not just your cisters"-is telling. Put in hooks' terms, we would do well to center the most marginal members of our group (2015, xviii). After all, promoting justice for queer women is in the interests of all women; cis-het women are not 'safe' from injustices relating to non-conforming sexual and gender identities, as this data makes clear. Further, when we focus on this type of activity, we can see how misogyny and queerphobia link up. And we cannot forget what the source of this oppression is; to paraphrase Moraga, while we all must initially struggle with the 'ism' that sits atop our own heads - whether that be heterosexism, sexism, cisgenderism, etc. - to fail to move from there towards one another will simply insulate rather than radicalize us (Moraga 1998, 29). It is clear that we must develop a stronger allyship with one another, and bringing this to explicit attention matters since, just as gender-motivated forms of harassment serve to inhibit women's full participation in public life, so too do these forms of online hate speech 
inhibit cis-het women's and queers' full participation in our cyber-social world through their coercive functioning (Mantilla 2013, 568). This is unjust and must be rectified.

\section{Concluding Remarks: How Can we Eliminate this Hate Speech?}

Classically misogynistic speech acts and, derivatively, cis-hetero-misogynistic speech acts are both forms of hate speech, and hence are one means of perpetuating women's and queers' oppression, it is obvious that we need to find ways to stop people from behaving thus. As discussed above, stronger allyship and critical epistemological meta-awareness is going to be central to this task. But what, specifically, can be done to prevent this type of speech from littering our social environment? It is commonly thought that the cybersphere presents unique challenges when it comes to controlling the proliferation of hate speech. Ease of access, the size of the audience, anonymity or, on this platform, hiding behind a fake profile, the instantaneousness of the message, as well as the (semi-)permanence of the message all factor in here (Brown 2017b; Waldron 2012).

An obvious first suggestion is that, whenever one encounters this speech, one undertakes to report it as hate speech to Facebook. Unfortunately, it is not clear that the identified speech meets Facebook's standard of hate. Facebook's definition sees hate speech as "a direct attack on people based on what we call protected characteristics - race, ethnicity, national origin, religious affiliation, sexual orientation, caste, sex, gender, gender identity and serious disease or disability." They define 'attack' as "violent or dehumanizing speech, statements of inferiority, or calls for exclusion or segregation" (Facebook Community Standards 2018). Though these women are being attacked (in part) because they are women, their womanhood is not overtly maligned; instead they are made to appear queer, where queerness is implicitly understood to be abnormal, deviant, and wrong. Furthermore, since many of the utterances are presented as jokes or social commentary, they would not warrant removal by Facebook's standards. And, as Judith Bannister rightly points out, such exemptions to hate speech bans "restrict the form of expression rather than the [degrading] message itself" (2008, 25). Clearly, this indicates that Facebook's definition of hate speech and its community standards must be updated, and we should lobby Facebook to do so (Brown 2017b). Though scholars rarely agree as to what hate speech is (Brown 2017a), for my part, I believe that Gelber's systemic discrimination approach $(2019,15-17)$ offers a working model that can inform policy reasonably successfully, and thus endorse this as a way of making concrete changes to get at the nuances of hate speech.

In Australia, similar problems might arise with a legislative approach. Although the Sex Discrimination Act 1984 (Cth) makes it unlawful to harass a person due to their gender (including gender status as well as gender identity), and although some states and territories have civil and criminal provisions for complaint of vilification on the basis of gender identity, gender status, and/or sexual orientation, it is not obvious that the identified speech would in fact be prohibited presently. Furthermore, because our laws are so fragmented, they arguably fail to provide sufficient protection to the very people who are targeted. So, Gelber's model could be useful here, too. But, while I endorse both of these approaches, it seems unlikely that punitive measures will address the source of this activity, and hence make online spaces safer for sex-, gender-, and orientation-diverse people - as well as cis-het women - to inhabit. This is not to say that laws are pointless, for, as Jeremy Waldron notes, their purpose is not only coercive, it is also expressive; they tell us the limits of tolerable behavior in our communities 
$(2012,80)$. But even if one could round up and punish all outwardly expressive cis-heteromisogynists, the problem of people engaging in cis-hetero-misogynistic speech acts would reoccur, because these ideas (and a willingness to express them) derive from the current cishetero-patriarchal gender order. To be clear, then, what I hope for is a both, and approach to this problem: both a punitive approach (institutional), and other strategies (allyship and critical meta-awareness) which aim to bring about an egalitarian gender order, recognizing that it is the latter which, ultimately, will reduce hate speech acts.

While Australia ascribes to the political ideology that differences do not render people morally inferior, what we need to do is to generate new social meanings for differencemeanings that are more liberating, less constraining, and which ultimately generate fairer social dynamics (Gatens 2004, 284-288) - rather than pretend our differences away in favor of focusing on our similarities. We must move beyond the hierarchical binaristic logic of A/Not-A which structures our encounters with difference, and consciously move to a logic of $A, B, C$, $D \ldots$ (Gatens 1991). This is radical insofar as it requires a complete reorientation in how one understands one's world, not just of how one relates to a specific group of people, such as cishet women or queers. But this is a project that requires interventions not simply at the level of belief, but also at the level of one's affective, visceral attachments to the dominant gender order. Still, to fix anything, we must have a nuanced understanding of the problem itself, and it is from this critical meta-awareness of the root causes of cis-hetero-misogynistic hate speech that I propose we proceed. How to establish this meta-awareness and greater allyship is the challenge we must collectively take up from this point forward.

Open Access This article is licensed under a Creative Commons Attribution 4.0 International License, which permits use, sharing, adaptation, distribution and reproduction in any medium or format, as long as you give appropriate credit to the original author(s) and the source, provide a link to the Creative Commons licence, and indicate if changes were made. The images or other third party material in this article are included in the article's Creative Commons licence, unless indicated otherwise in a credit line to the material. If material is not included in the article's Creative Commons licence and your intended use is not permitted by statutory regulation or exceeds the permitted use, you will need to obtain permission directly from the copyright holder. To view a copy of this licence, visit http://creativecommons.org/licenses/by/4.0/.

\section{References}

Baltzly D (2003) Peripatetic perversions: a neo-Aristotelian account of the nature of sexual perversion. Monist $86: 3-29$

Bannister J (2008) It's not what you say but the way that you say it: Australian hate speech laws and the exemption of 'reasonable' expression. Fla State Univ Law Rev 36:23-40

Beauvoir S de (1949 [2009]). The second sex. Trans: Borde C, Malovany-Chevallier S. London: Vintage Books

Brown A (2017a) What is hate speech? Part I: the myth of hate. Law Philos 36:419-468

Brown A (2017b) What is so special about online (as compared to offline) hate speech? Ethnicities 18:297-326

Calhoun C (2000) Feminism, the family, and the politics of the closet: lesbian and gay displacement. Oxford University Press, Oxford

Currah P, Stryker S, Galarte FJ (eds) (2014) Postposttranssexual: key concepts for a 21st century transgender studies. TSQ 1-2:19-272

Facebook Community Standards (2018) 12. Hate Speech. Facebook. https://www.facebook. com/communitystandards/hate_speech/. Accessed 7 December 2018

Facebook Newsroom (2017) Stats. Facebook. https://newsroom.fb.com/company-info/. Accessed 1 March 2018

Gatens M (1991) Feminism and philosophy: perspectives on difference and equality. Contemp Political Theory. Polity Press, Cambridge

Gatens M (2004) Can human rights accommodate women's rights? Towards an embodied account of social norms, social meaning, and cultural change. Contemporary Political Theory 3:275-299

Gelber K (2019) Differentiating hate speech: a systemic discrimination approach. Crit Rev Int Soc Pol Phil:1-22. https://doi.org/10.1080/13698230.2019.1576006 
Grosz E (1989) Sexual subversions: three French feminists. Allen \& Unwin, St Leonards

Hooks B (2015) Feminist theory: from margin to center. Routledge, New York

Hunt S (2018) Inside the war memorial. In: Eades Q, Vivienne S (eds) Going postal: more than 'yes' or 'no'. Brow Books, Australia, pp 134-143

Jay N (1981) Gender and dichotomy. Fem Stud 7:38-56

Langton R (2012) Beyond belief: pragmatics in hate speech and pornography. In: Maitra I, McGowan MK (eds) Speech and harm: controversies over free speech. Oxford University Press, Oxford, pp 72-93

Manne K (2018) Down girl: the logic of misogyny. Oxford University Press, Oxford

Mantilla K (2013) Gendertrolling: misogyny adapts to new media. Fem Stud 39:563-570

Moraga C (1998) La Güera. In: Anderson M, Collins PH (eds) Race, class, and gender: an anthology. Wadsworth Publishing, Belmont, pp 26-33

Rich A (1980) Compulsory heterosexuality and lesbian existence. Signs 5:631-660

Richardson-Self L (2015) Justifying same-sex marriage: a philosophical investigation. Rowman \& Littlefield International, London

Richardson-Self L (2018a) Same-sex marriage and the 'no' campaign. Humanities Australia 9:32-39

Richardson-Self L (2018b) Woman-hating: on misogyny, sexism, and hate speech. Hypatia: a journal of feminist philosophy 33:256-272

Roy Morgan Research Institute (2017) Sydney Morning Herald is still Australia's most widely read masthead and Australians continue to embrace the shift to digital news. Finding No. 7306. http://www.roymorgan. com/findings/7306-roy-morgan-australian-newspaperreadership-june-2017-201708101543. Accessed 1 March 2018

Scharff C (2012) Repudiating feminism: young women in a neoliberal world. Ashgate Publishing Limited, Surrey

Valdes F (1996) Unpacking hetero-patriarchy: tracing the conflation of sex, gender \& sexual orientation to its origins. Yale J Law Humanit 8:161-211

Waldron J (2012) The harm in hate speech. Harvard University Press, Cambridge

Publisher's Note Springer Nature remains neutral with regard to jurisdictional claims in published maps and institutional affiliations. 